\title{
Accounting
}

\section{The estimation of banking industry staffing level benchmark: A case study on Kuwaiti banks}

\author{
Yaser A. AlKulaib ${ }^{a^{*}}$ and Musaed S. AlAli ${ }^{b}$
}

\begin{abstract}
${ }^{a}$ Assistant Professor, Department of Finance and Financial Institutions, College of Business Administration, Kuwait University, Kuwait
${ }^{b}$ Assistant Professor, Department of Insurance and Banking, College of Business Studies, The Public Authority for Applied Education and Training
\end{abstract} (PAAET), Kuwait

\section{H R O N I C L E}

\section{Article history:}

Received: September 2, 2020

Received in revised format:

September 302020

Accepted: October 8, 2020

Available online:

October 8, 2020

Keywords:

Staffing Level

Kuwait Banks

Kuwait Stock Exchange (KSE)

Overstaffing

Understaffing

\section{A B S T R A C T}

This study aims to examine whether or not Kuwaiti banks are overstaffed based on the data of ten Kuwaiti banks listed at Kuwait stock exchange (KSE) over the period 2010-2018. Using panel regression analysis, the results show that six banks were overstaffed while the remaining four banks were understaffed. Kuwait Finance House (KFH) was the most overstaffed bank in Kuwait while Commercial bank was the most understaffed bank. Gulf bank was the closest to the estimated number of staff followed by AlAhli bank. The results also revealed that there was a statistically significant inverse relationship between staffing level and return on assets (ROA) while, on the other hand, there was a statistically significant direct relationship between total assets and the number of branches with staffing level.

\section{Introduction}

Determining the optimal staffing level has been a debatable issue in literature. While there is no magical formula that can be applied to all economic sectors, Reeves (2002) suggests that industry benchmarks are the best way to estimate the optimal staffing level. He criticized the reactional approach where the organization hires more staff during the high business periods and fire them during the low business periods when the overhead cost becomes high that it will affect the organization financial position. This approach will result in future uncertainty among the staff which in turn will affect their productivity. Researchers such as Treville and Antonakis (2006) see that moderate understaffing would yield a better performance since the employees tend be more efficient and experience higher motivation. Gralla and Kraft (2012) found that employees in understaffed organizations tend to receive more compensation for their work compared to employees in overstaffed organizations. On the other hand, such high work pressure might lead to a higher stress and higher emotional exhaustion resulting in reduced motivation, lower productivity, poor performance and a higher human error rates (Ahmed, 2007; Rafferty et al., 2007; Rochefort \& Clarke, 2010). Maxham et al. (2008) found that understaffing leads to job dissatisfaction which he found to be positively linked to the organization financial performance. In slightly overstaffed condition employees tend to suffer less from burnout, have higher job satisfaction, and to have better work-life balance. As a result, they would be more productive and provider of

* Corresponding author

E-mail address: yalkulaib@.cba.edu.kw (Y.A. AlKulaib) 
higher quality services (Rafferty et al., 2007). Tran and Davis (2012) also concluded that slightly overstaffing would not affect the organization profitability but understaffing and too much overstaffing conditions would have a great effect on organization profitability. Study conducted by Tran and Davis (2011) also concluded that organizations with slight overstaff tend to be the most profitable. According to Reeves (2002), even though overstaffed organizations have a higher personnel cost and workers work in a less stressed environment, this does not necessarily mean better financial performance for the organization. In examining the effect of staffing level on the financial performance of Kuwaiti banks, AlAli (2020) conducted a study using the data of 10 Kuwaiti banks listed at Kuwait stock exchange (SKE) over the period 2008-2018. Results of the research showed that there was no statistically significant relation between the two variables.

The level of staffing in banks has seen a global decline in the past years due to the introduction of technology aided banking, such as e-banking and m-banking, (AlAli and AlAli, 2020). According to EY-Global banking outlook (2018), it is estimated that $62 \%$ of banks are expected to become digitally mature or digital leaders by 2020 . This would lead to huge reduction in staff especially in the retail banking sector. At the end of 2017, British banks closed 762 local branches in an attempt to reduce cost and encourage customers to use online banking (Camp, 2018). Even though the staffing level in the banking sector has been reduces around the world, in Kuwait the staffing level has been increasing by $2.48 \%$ annually during the study period as seen in Fig. 1. The reason for the increase in staff numbers is due to the nationalization law that forces banks to nationalize at least $70 \%$ of their staff.

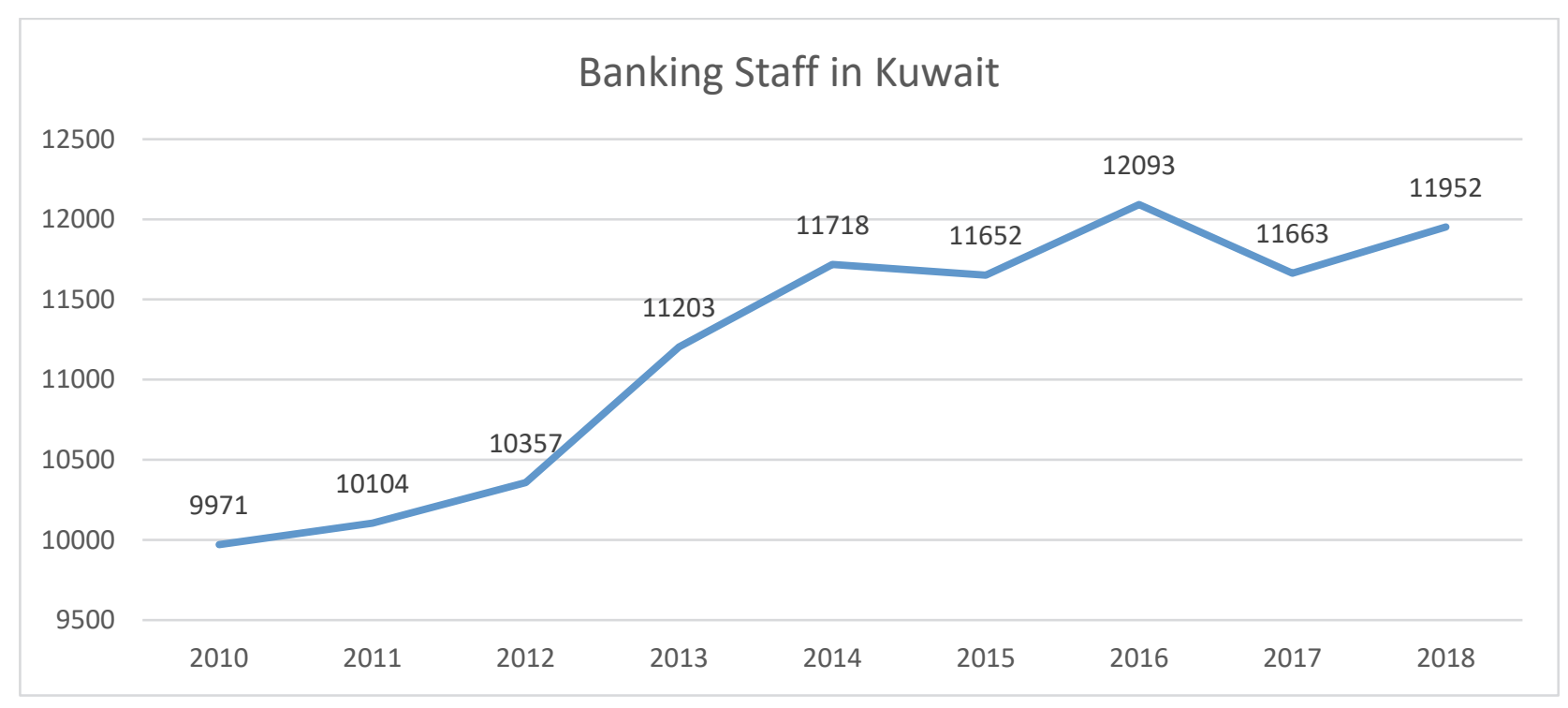

Fig.1. Number of Staff in Kuwaiti Banks

\section{Methodology}

This study aims to first identify which Kuwaiti banks are overstaffed. In order to estimate the optimal number of staff needed, a panel regression analysis is conducted using Eq. (1), as follow;

$$
\widehat{\operatorname{lnSt}}_{t}=\alpha+\beta_{1} R O A_{t}+\beta_{2} \ln T A_{t}+\beta_{3} S O P_{t}+\beta_{3} \ln B r_{t}
$$

where $\widehat{l n S t}_{t}$ is the natural logarithm of the estimated number of staff required by the bank, $R O A$ is the return on assets, $T A$ is the total assets of the bank, $S O$ is the bank staff expense to operating income, and $\mathrm{Br}$ is the number of branches the bank has. In order to examine whether the bank is overstaffed or understaffed, the difference between the estimated numbers of staff is deducted from the actual number of staff as shown in Eq. (2);

$$
\triangle S t_{t}=S t_{t}-\exp \widehat{\operatorname{lnSt}}_{t}
$$

\section{Data and Empirical Results}

This research is based on the financial data of 10 Kuwaiti banks that are listed at Kuwait stock exchange over the period 20102018. The data for this research were downloaded from Kuwait Institute of Banking Studies (KIBS) website.

Descriptive analysis presented in Table 1 shows that in Kuwait the average number of staff in banks is 1144 employees. The average return on assets (ROA) was $0.93 \%$ with an average number of local branches of 39 branch per bank. Using the threshold 
of \pm 1.96 for skewness and \pm 10 for kurtosis, it can be seen from the table that all the variables lie within the acceptable range of normal distribution.

Table 1

Descriptive Analysis

\begin{tabular}{|c|c|c|c|c|c|}
\hline & Staff & $\mathrm{ROA}$ & TA & SOP & Branch \\
\hline Mean & 1144.47 & 0.93 & 6564.47 & 0.81 & 39.20 \\
\hline Median & 823.50 & 0.97 & 4137.60 & 0.73 & 37.00 \\
\hline Standard Deviation & 684.75 & 0.51 & 6479.39 & 0.56 & 17.68 \\
\hline Kurtosis & -0.34 & 2.98 & 2.04 & 8.01 & -1.07 \\
\hline Skewness & 0.98 & -0.72 & 1.68 & 1.21 & 0.10 \\
\hline Count & 88 & 88 & 88 & 88 & 88 \\
\hline
\end{tabular}

Pearson correlation matrix is set to examine the direction and the strength of the relation between the variable. The matrix is also used to detect multicollinearity which can cause unrealistically high standard error estimates of regression coefficients and in the end can cause false conclusion about the significance of independent variables in the model being evaluated. The threshold used to examine multicollinearity between the variables is 0.70 . From Table 2 , it can be seen that there is no multicollinearity between the variables.

Table 2

Pearson Correlation Matrix

\begin{tabular}{cccccc}
\hline & Staff & ROA & TA & & \\
\hline Staff & 1 & & & & \\
BOAnch & 1 & 1 & \\
TA & 0.350 & 0.370 & -0.218 & \\
SEOP & 0.873 & -0.464 & 0.762 & 1 \\
Branch & -0.142 & 0.425 & -0.284 & 1 \\
\hline
\end{tabular}

Results of Eq. (1) are presented in Table 3. Results show that the model can be labeled as a "good fit" since Sig F is less than 0.05 . The model also has a good explanatory power with an adjusted $R$ square of 0.890 indicating that the model was able to capture $88.82 \%$ of the variation in the number of staff. The table also reveals that there was an inverse relationship between return on assets (ROA) and staffing level indicating that the more overstaffed the bank is, the lower return on assets (ROA) the bank makes. On the other hand, the model shows a statistically significant direct relation between total assets the bank has and the number of branches with the staffing level.

Table 3

OLS Panel Regression Output

\begin{tabular}{|c|c|c|c|c|}
\hline & Coefficients & Standard Error & $t$ Stat & $P$-value \\
\hline Intercept & 2.523 & 0.2036 & $12.393 * * *$ & 0.00 \\
\hline ROA & -0.099 & 0.0507 & $-1.954 *$ & 0.054 \\
\hline $\operatorname{lnTA}$ & 0.272 & 0.0423 & $6.418 * * *$ & 0.00 \\
\hline SOP & 0.0039 & 0.0043 & 0.9117 & 0.365 \\
\hline $\ln \mathrm{Br}$ & 0.6122 & 0.0718 & $8.5289 * * *$ & 0.00 \\
\hline
\end{tabular}

$*, * *, * * *$ indicate confidence level at $90 \%, 95 \%$, and $99 \%$ respectively.

Adjusted R Square $=0.8882$ Standard Error $=0.1951$ Significance $F=0.00$ Observations $=88$

From the OLS regression results presented in Table 2, the optimal staffing number needed per bank can be estimated by;

$$
\widehat{\operatorname{lnSt}}_{t}=2.523-0.099 \mathrm{ROA}_{t}+0.272 \operatorname{lnT} A_{t}+0.0039 \mathrm{SOP}_{t}+0.6122 \operatorname{lnBr} t
$$

By plotting Eq. (4), it can be seen from Table 4, that $60 \%$ of Kuwaiti banks suffer from overstaffing while $40 \%$ of them do not. Kuwait Finance House was the most overstaffed bank in Kuwait followed by Boubyan bank during the study period where they had $28.58 \%$ and $23.21 \%$ overstaffing, respectively. On the other hand, Commercial bank was the most understaffed bank in Kuwait where the bank was understaffed by 276 employees. Both overstaffing and understaffing have negative effects on banks' business and financial performance. When a bank is overstaffed, this would mean a higher payrolls expense which in turn affects the profitability of the bank. On the flip side, employees in an understaffed bank feels tension and stressed due to the high work load which in turn can result in a high employee's turnover ratio. In order to avoid these two scenarios banks should be as close to the projected staffing number as possible. For that matter it can be seen that Gulf bank was the closest to the projected number with an overstaffing of $4.00 \%$ followed by AlAhli bank that had an understaffing of $4.47 \%$. 
Table 4

Banks Under/Overstaffing

\begin{tabular}{|c|c|c|c|c|}
\hline & Actual Staff & Estimated Staff & Under/Overstaffing* & $\%$ \\
\hline AlAhli Bank & 801 & 845 & -44 & $-4.47 \%$ \\
\hline Burgan Bank & 710 & 924 & -214 & $-22.82 \%$ \\
\hline Commercial Bank & 913 & 1189 & -276 & $-22.84 \%$ \\
\hline Gulf Bank & 1470 & 1413 & 56 & $4.00 \%$ \\
\hline National Bank of Kuwait & 2207 & 2072 & 135 & $7.67 \%$ \\
\hline Ahli United Bank & 753 & 880 & -126 & $-13.99 \%$ \\
\hline Boubyan Bank & 963 & 776 & 187 & $23.21 \%$ \\
\hline Kuwait Finance House & 2496 & 1940 & 555 & $28.58 \%$ \\
\hline Kuwait International Bank & 630 & 589 & 41 & $7.61 \%$ \\
\hline Warba Bank & 319 & 309 & 11 & $8.94 \%$ \\
\hline
\end{tabular}

*(-) indicate understaffing

\section{Conclusion}

Determining the optimal staffing level is an ongoing process where the level changes based on the bank operational activities. This study aims to develop a model that is able to estimate the optimal staffing level required by banks in Kuwait. The model is based on OLS panel regression model that uses return on assets (ROA), total assets, staff expense to operating profit, and number of branches to determine the number of staff needed in the bank. Based on the model developed, results have shown that six banks suffered from overstaffing while the remaining four were understaffed.

\section{References}

Ahmed, H. (2007). Improved operations through manpower management in the oil sector, Journal of Petroleum Science and Engineering, 55(1-2), 187-199.

AlAli, M. S. (2020). Staffing Level, Wages and Banks Financial Performance, International Research Journal of Finance and Economics, 180, 48-53.

AlAli, L. S., \& AlAli, M. S. (2020). Exploring factors influencing mobile-banking usage among PAAET college of business studies students. International Journal of Computer Science and Mobile Computing, 9(4), 95-104.

Camp, S. (2018). Is AI leading to job loss in banking?, Outside inside. Available at: https://outsideinsight.com/insights/is-aileading-to-job-loss-in-banking/

Gralla, R., \& Kraft, K. (2012). Higher Wages, Overstaffing or Both? The Employer's Assessment of Problems Regarding Wage Costs and Staff Level in Co-Determined Establishments. IZA Discussion Paper No. 7021, Available at SSRN: https://ssrn.com/abstract=2186799

EY- Global banking outlook (2018) available at: https://www.ey.com/Publication/vwLUAssets/ey-global-banking-outlook2018/\$File/ey-global-banking-outlook-2018.pdf

Maxham III, J. G., Netemeyer, R. G., \& Lichtenstein, D. R. (2008). The retail value chain: linking employee perceptions to employee performance, customer evaluations, and store performance. Marketing Science, 27(2), 147-167.

Rafferty, A. M., Clarke, S. P., Ball, J., James, P., McKee, M., \& Aiken, L. H. (2007). Outcomes of Variation in Hospital Nurse Staffing in English Hospitals: Cross-Sectional Analysis of Survey Data and Discharge Records, International Journal of Nursing Studies, 44(2), 175-182.

Reeves, C. S. (2002). How many staff members do you need?, Family Practice Management, 9(8), 45-49.

Rochefort, C. M., \& Clarke, S. P. (2010). Nurses' work environment, care rationing, job outcomes, and quality of care on neonatal units. Journal of Advanced Nursing, 66, 2213-2224.

Tran, T. B., \& Davis, S. R. (2011). A quantitative approach to measure organization performance. International Journal of Social Science and Humanity, 1(4), 289-293.

Tran, T. B., \& Davis, S. R. (2012). Staffing and organization performance - supports for a slight overstaffing level. Proceedings of 19th International Business Research Conference 2012, Available at https://ssrn.com/abstract=2174205 or http://dx.doi.org/10.2139/ssrn.2174205

Treville, S., \& Antonakis, J. (2006). Could lean production job design be intrinsically motivating? Contextual, configurational, and levels-of-analysis issues. Journal of Operations Management, 24(2), 99-123.

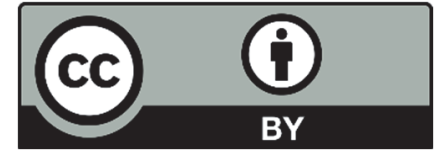

(C) 2021 by the authors; licensee Growing Science, Canada. This is an open access article distributed under the terms and conditions of the Creative Commons Attribution (CC-BY) license (http://creativecommons.org/licenses/by/4.0/). 